Law \& Economics Working Papers

Law \& Economics Working Papers Archive:

2003-2009

\title{
A PROPOSAL TO ADOPT \\ FORMULARY APPORTIONMENT \\ FOR CORPORATE INCOME TAXATION: THE HAMILTON \\ PROJECT
}

Reuven S. Avi-Yonah* Kimberly Clausing ${ }^{\dagger}$ 


\section{A Proposal to Adopt Formulary Apportionment for Corporate Income Taxation}

\section{The Hamilton Project}

Third Draft: April 2007

Reuven S. Avi-Yonah

Irwin I. Cohn Professor of Law

University of Michigan Law School

Ann Arbor, MI 48109

Phone: 734.647 .4033

Fax: 734.763.9375

E-mail: aviyonah@umich.edu
Kimberly A. Clausing

Associate Professor of Economics Wellesley College

Wellesley, MA 02481

Phone: 781.283.2161

Fax: 781.283.2177

Email: clausing@wellesley.edu 


\section{Introduction ${ }^{1}$}

The current system of taxing the income of multinational firms in the United States is flawed across multiple dimensions. The system provides an artificial tax incentive to earn income in low-tax countries, rewards aggressive tax planning, and is not compatible with any common metrics of efficiency. The U.S. system is also notoriously complex; observers are nearly unanimous in lamenting the heavy compliance burdens and the impracticality of coherent enforcement. Further, despite a corporate tax rate one standard deviation above that of other OECD countries, the U.S. corporate tax system raises relatively little revenue, due in part to the shifting of income outside the U.S. tax base.

In this proposal, we advocate moving to a system of formulary apportionment for taxing the corporate income of multinational firms. Under our proposal, the U.S. tax base for multinational corporations would be calculated based on a fraction of their worldwide income. This fraction would simply be the share of their worldwide sales that occur in the United States. This system is similar to the current method that U.S. states use to allocate national income across states. ${ }^{2}$ The state system arose due to the widespread belief that it was impractical to account separately for what income is earned in each state when states are highly integrated economically. Similarly, in an increasingly global world economy, it is difficult to assign profits to individual countries, and attempts to do so are fraught with opportunities for tax avoidance.

\footnotetext{
${ }^{1}$ The authors acknowledge valuable feedback from Rosanne Altshuler, Mihir Desai, Jon Talisman, Michael Durst, Michael Knoll, Reed Schuldiner, Chris Sanchirico, Joann Weiner, Diane Ring, Yariv Brauner, Joseph Guttentag, Philip West, and the Hamilton Project staff, especially Peter Orszag, Jason Bordoff, and Michael Deich.

${ }^{2}$ We should note, however, that our proposal is significantly different from current state tax law, in ways discussed below.
} 
Under our proposed formulary apportionment system, firms would no longer have an artificial tax incentive to shift income to low-tax locations. This would help protect the U.S. tax base while reducing the distortionary features of the current tax system. In addition, the complexity and administrative burden of the system would be reduced. The proposed system would be both better suited to an integrated world economy and more compatible with the tax policy goals of efficiency, equity, and simplicity.

The following section will discuss the current U.S. system and describe its flaws. Section III will describe our proposed formulary apportionment system, discuss its advantages, and clarify how the proposal addresses the flaws of the current system. Section IV will address potential hurdles and problems associated with formulary apportionment, including implementation issues. Section V will conclude, briefly contrasting this proposal with other reform suggestions.

\section{The U.S. System of Corporate Taxation}

Under the current tax system, multinational firms (both resident and non-resident) pay tax to the U.S. government based on the income that they report earning in the United States. As is typical, the United States employs a separate accounting (SA) system, where firms account for income and expenses in each country separately. The current U.S. tax rate is 35 percent. Figure $1 \mathrm{~A}$ shows the evolution of corporate tax rates for OECD countries over the past quarter century. As is clear from this diagram, the U.S. statutory corporate tax rate has been increasing relative to other OECD countries over the 
previous 15 years, and it is now one standard deviation higher than the average OECD tax rate. ${ }^{3}$

The U.S. government taxes U.S. multinational firms on a residence basis, and thus U.S. resident firms incur taxation on income earned abroad as well as income earned in the United States. This system is sometimes referred to as a credit system, as U.S. firms receive a tax credit for taxes paid to foreign governments. The tax credit is limited to the U.S. tax liability although firms may generally use excess credits from income earned in high-tax countries to offset U.S. tax due on income earned in low-tax countries, a process known as cross-crediting. Taxation only occurs when income is repatriated. ${ }^{4}$ Thus, income can grow free of U.S. tax prior to repatriation, a process known as deferral. Deferral and cross-crediting provide strong incentives to earn income in low-tax countries. There is also typically an incentive to avoid income in high-tax countries due to the limited tax credit.

As an example, consider a U.S. based multinational firm that operates a subsidiary in Ireland. Assume that the U.S. corporate income tax rate is 35\% while the Irish corporate income tax rate is $12.5 \%$. The Irish subsidiary earns $\square 800$ and decides to repatriate $\square 70$ of the profits to the United States. (Assume, for ease of computation only, a 1:1 exchange rate.) First, the Irish affiliate pays $\square 100$ to the Irish government on profits of $\square 800$. It then repatriates $\$ 70$ to the United States, using the remaining profit ( $\square 630$ ) to reinvest in its Irish operations. The firm must pay U.S. tax on the repatriated income, but it is eligible for a tax credit of $\$ 100$ (taxes paid) times 70/700 (the ratio of

\footnotetext{
${ }^{3}$ The trends for average effective tax rates are similar. See Figure 1, panel B.

${ }^{4}$ The Subpart F provisions of U.S. tax law prevent some firms from taking full advantage of deferral. Under Subpart F, certain foreign income of controlled foreign corporations is subject to immediate taxation. This includes income from passive investments.
} 
dividends to after-tax profits), or \$10. This assumes that the U.S. multinational firm does not have excess foreign tax credits from its operations in high-tax countries; if it does, it can use these credits to offset taxes due on the repatriated Irish profits. Due to deferral, the remaining profits ( $\square 630$ ) can grow abroad tax-free prior to repatriation.

This system creates a clear incentive to earn profits in low-tax countries. Firms may respond by locating real activities (jobs, assets, production) in low-tax countries. In addition, firms respond by shifting profits to low-tax locations, disproportionate to the scale of business activities in such locations. There are multiple ways to shift income among countries. For example, it may be advantageous for multinational firms to alter the debt/equity ratios of affiliated firms in high and low-tax countries in order to maximize interest deductions in high-tax countries and taxable profits in low-tax countries. Further, multinational firms have an incentive to distort the prices on intrafirm transactions in order to shift income to low-tax locations. For example, firms can follow a strategy of under- (over-) pricing intrafirm exports (imports) to (from) low-tax countries, following the opposite strategy with respect to high-tax countries. ${ }^{5}$

In theory, firms should be limited in their ability to engage in tax-motivated transfer pricing by fear of detection. Governments generally employ an "arm’s length” standard, requiring multinational firms to price intrafirm transactions as if they were occurring at arm's length. Nonetheless, there is universal agreement that this standard leaves substantial room for tax incentives to affect pricing, as arm's length prices are often difficult to establish for many intermediate goods and services. Further, as argued below, the arm’s length standard has become administratively unworkable in its

\footnotetext{
5 There are numerous other margins along which income shifting incentives influences multinational firm behavior, including the location of intangible property, the payment of royalties, and the timing and planning of repatriation decisions.
} 
complexity. As a result, the arm's length standard rarely provides useful guidance regarding economic value.

Some countries (such as the U.K and Japan) use a tax credit system similar to that used by the United States. Still, others (such as France and the Netherlands) exempt most foreign income from taxation; this is referred to as a territorial system of international taxation. In theory, multinational firms based in these countries have an even greater incentive to incur income in low-tax countries as such income will not typically be taxed upon repatriation. Still, some authors argue that excess foreign tax credits and deferral blur the distinction between these two systems. ${ }^{6}$

Shortly before the 2004 election, the U.S. Congress passed the American Jobs Creation Act. The international tax provisions of this law represent a somewhat subtle shift toward a territorial system of taxing international income in the United States. For example, the legislation contained a provision to allow a temporary tax holiday for dividend repatriations of 5.25 percent; this provided a substantial tax advantage to repatriate funds from low-tax countries in the year of the tax break.

On net, this holiday made investments in low-tax countries more attractive relative to the prior status quo, as there was now the promise of methods for repatriating profits without incurring large tax costs. In addition, other measures of the legislation permanently lighten the taxation on foreign income, including provisions that facilitate cross-crediting as well as changes in the interest allocation rules. ${ }^{7}$ Recently, George Yin,

\footnotetext{
${ }^{6}$ See, e.g., Altshuler (2000). de Mooij and Ederveen (2003) find evidence in support of this view. In addition, several countries have hybrid systems that lie in between these two systems; for instance, foreign income may be exempt from taxation in the home country provided that the foreign country's tax system is sufficiently similar to that in the home country.

${ }^{7}$ See Avi-Yonah (2005), Clausing (2005), and Fleming and Peroni (2004) for a more detailed discussion and analysis of these provisions.
} 
the former chief of staff of the Joint Committee on Taxation, concluded that the American Jobs Creation Act indeed takes the U.S. system of taxation closer to a territorial system, and speculated that future tax policy could move further in that direction. $^{8}$

\section{Problems with the Current System of Corporate Taxation}

The current system of corporate taxation has both conceptual and practical weaknesses. First, the system is not suited to the global nature of international business. In particular, international production processes make the separate accounting (SA) system of assigning profit to specific geographic destinations inherently arbitrary. Further, the very nature of multinational firm operations generates additional profit over what would occur with strictly arms-length transactions between unaffiliated entities. Theories of multinational firms emphasize that they arise in part due to organizational and internalization advantages relative to purely domestic firms; such advantages imply that profit is generated in part by internalizing transactions within the firm. Thus, with firms that are truly integrated across borders, holding related entities to an "arms-length" standard for the pricing of intracompany transactions does not make sense, nor does allocating income and expenses on a country-by-country basis. In fact, a very similar logic was behind the use of formulary apportionment (FA) for U.S. state governments; with an integrated U.S. economy, it does not make sense to attribute profits and expenses to individual states, nor to regulate transfer prices between entities of different states.

Also, the current system is based on an artificial distinction among legal entities. For example, companies are taxed differently based on whether they employ subsidiaries or branches; as one example, deferral of taxation on unrepatriated profits is allowed for

\footnotetext{
${ }^{8}$ See Glenn (2004).
} 
the former but not the later. Recently, there has been an increasingly common use of hybrid entities (treated as subsidiaries by one country and branches by another) to achieve double non-taxation.

Another related problem is that the current system is based on an increasingly artificial distinction between multinational enterprises whose parent is incorporated in the United States and those whose parent is incorporated elsewhere. The former, but not the latter, are subject to world-wide taxation with its attendant complexities (primarily the foreign tax credit and Subpart F). But in today's world, this distinction is less and less meaningful as the sources of capital, location of $R \& D$, location of production, and location of distribution of MNEs become increasingly globalized. The current distinction has led to a spate of inversion transactions, in which US-based MNEs formally shift the location of incorporation of their parent offshore without changing the location of any of their real business activities. Arguably, it has also encouraged takeovers of US-based MNEs by larger foreign-based ones who can benefit from territorial systems of taxation.

Second, as explained above, the current U.S. system of international taxation creates an artificial tax incentive to locate profits in low-tax countries, both by locating real economic activities in such countries and by shifting profits toward more lightly taxed locations. It is apparent that U.S. multinational firms book disproportionate amounts of profit in low-tax locations. For example, Figure 2 shows the top ten profit locations for U.S. multinational firms in 2003, based on the share of worldwide (nonU.S.) profits earned in each location. While some of the countries are places with a large U.S. presence in terms of economic activity (the United Kingdom, Canada, Germany, 
Japan), seven of the top-ten profit countries are locations with very low effective tax rates.

The literature has consistently found that multinational firms are sensitive to corporate tax rate differences across countries in their financial decisions. Estimates from the literature suggest that the tax base responds to changes in the corporate tax rate with an average semi-elasticity of about -2 ; thus, countries with high corporate tax rates are likely to gain revenue by lowering their tax rate. ${ }^{9}$ One recent study suggests that corporate income tax revenues in the United States were approximately 35\% lower due to income shifting in 2002. ${ }^{10}$

This problem has worsened as U.S. corporate rates have become increasingly out of line with other countries. In the past twenty years, most OECD countries have lowered their corporate income tax rates, whereas U.S. rates have been relatively constant. This increasing discrepancy between U.S. rates and foreign rates likely results in increasing amounts of lost revenue for the U.S. government due to strengthening income shifting incentives.

Also, the literature suggests a substantial real responsiveness to tax rate differences among countries, with average semi-elasticities of real activity with respect to the corporate income tax rate of about $-2 .^{11}$ These findings imply both less activity in United States and less tax revenue for the U.S. government. However, the tax responsiveness of real activity is less immediately apparent in the data. For example, Figure 3 shows the top ten employment locations for U.S. multinational firms in 2003,

\footnotetext{
${ }^{9}$ See de Mooij (2005) for an overview of this literature.

10 This estimate is from Clausing (2007b). The calculation is based on a regression of U.S. multinational firm affiliate profit rates on tax rate differences across countries. See Appendix A for more details.

${ }^{11}$ See de Mooij (2005).
} 
based on the share of worldwide (non-U.S.) employment in each location. The high employment countries are the usual suspects - large economies with close economic ties to the United States. As the accompanying table indicates, tax rates are not particularly low for this set of countries.

Third, the current system is absurdly complex. As Taylor (2005) notes, observers have described the system as "a cumbersome creation of stupefying complexity” with “rules that lack coherence and often work at cross purposes.” Altshuler and Ackerman (2005) note that observers testifying before the President's Advisory Panel on Federal Tax Reform found the system “deeply, deeply flawed”, noting that "It is difficult to overstate the crisis in the administration of the international tax system of the United States.”

Fourth, particularly given the high U.S. corporate statutory tax rates, the U.S. corporate tax system raises relatively little revenue. Figure 4 shows the evolution of government corporate tax revenues relative to GDP for OECD countries. For most OECD countries, revenues have increased as a share of GDP even as corporate tax rates have declined; the average OECD country receives 3\% of GDP from corporate tax revenue by the end of the sample. Most observers attribute this trend to a broadening of the tax base for many OECD countries during this time period. For the United States, revenues are lower; although they fluctuate with the cyclical position of the economy, they tend to be closer to $2 \%$ of GDP. There are several plausible reasons for the lower amount of U.S. revenue, including the increasingly aggressive use of corporate tax 
shelters, a narrower corporate tax base, and stronger incentives for tax avoidance, which tend to increase as the U.S. tax rate is high relative to other countries. ${ }^{12}$

\section{A Proposal to Adopt Formulary Apportionment}

Our proposal would address most of the aforementioned flaws with the current system of corporate taxation. Under formulary apportionment (FA), tax liabilities would reflect truly globally integrated business, and they would not be dependent on artificial distinctions among legal entities. Under FA, unlike separate accounting (SA), firms would have no incentive to shift income across countries, as tax liabilities would be based on total world income as well as the share of a firm's sales that occur in each destination. Since there would be no tax savings associated with shifting income across countries, the overall incentive to locate real activities in low-tax countries would also be reduced.

Further, absent income shifting, U.S. government revenues would be higher. If the proposal offered here were implemented in a revenue neutral fashion, it would enable a substantial cut in the corporate income tax rate. Since the proposed system could entail dramatic simplification and help finance a corporate tax rate reduction, there is justification for corporate support.

\section{How Would Formulary Apportionment Work?}

Under formulary apportionment, a unitary business is defined based on whether the parent corporation exercises legal and economic control over its subsidiaries. That unitary business is treated as a single taxpayer and its income is calculated by subtracting worldwide expenses from worldwide income, based on a global accounting system,

\footnotetext{
${ }^{12}$ Auerbach (2006) also notes that there is a declining ratio of nonfinancial C corporation profits, although he notes that this is offset by an increasing average tax rate due to the increasing importance of tax losses.
} 
without regard to legal distinctions among units. The resulting net income is apportioned among taxing jurisdictions based on a formula that takes into account various factors. Each jurisdiction then applies its tax rate to the income apportioned to it by the formula and collects the amount of tax resulting from this calculation.

Our proposed system would utilize a sales based formula. ${ }^{13}$ In the experience of U.S. states, income has been allocated to state jurisdictions using a variety of formulas. Historically, many US states have used the so-called "Massachusetts formula” which employs equal weights on property, payroll and sales. For example, under an equalweighted formula apportionment system, tax liability to the U.S. government would be based on the U.S. tax rate times the fraction of worldwide profits that are attributed to the United States. This fraction would be based on how much of worldwide economic activity (an average of sales, assets, and payroll shares) occurs in the United States.

Observers have noted that a FA system creates an implicit tax on the factors used in the formula, thus discouraging assets and employment in high-tax locations. This formula also leaves unresolved issues concerning the treatment of intangible property, how to value property, etc. In part due to these concerns, we propose a far simpler formula, which would only consider the fraction of sales in each location. Sales would be determined on a destination-basis, based on the location of the customer rather than the location of production. We propose this destination-basis sales formula for several reasons; alternative formulas are also discussed in Appendix B.

\footnotetext{
${ }^{13}$ A similar proposal has been advocated by Durst (2007), who offers legislative language for implementing a formulary approach to corporate taxation. He notes that technical barriers to adopting FA have been overstated; defining a unitary group and establishing the destination of sales are both attainable objectives.
} 
The key advantage of a sales-based formula is that sales are far less responsive to tax differences across markets, as the customers themselves are far less mobile than firm assets or employment. Even in a high-tax country, firms still have an incentive to sell as much as possible. In addition, if some countries adopt sales-based formulas, other countries will have an incentive to adopt sales based formulas as well in order to avoid losing payroll or assets to countries in which these factors are not part of the formula.

The U.S. state experience reinforces the merits of this proposal. In recent years, many US states have shifted to a formula that double-weights the sales factor, often based on a desire to encourage exports out of state and discourage imports. State incentives to move toward a sales-based formula are well documented. For example, Edminston (2002) generates a model with this prediction, and Omer and Shelley (2004) document this trend empirically. Goolsbee and Maydew (2000) demonstrate that U.S. states that lower the weight on the payroll factor experience increases in manufacturing employment. According to Weiner (2005), 23 states double weight sales as of 2004, and 7 others have an even larger weight on sales. Some states even use a sales-only formula (which was approved for Iowa by the Supreme Court).

In addition, international experience suggests that movement toward a sales-based formula is likely. Because of the widespread belief that imposing taxes on imports and exempting exports boosts national competitiveness and reduces trade deficits, it is possible that if some countries were to adopt a sales-based formula for apportioning corporate income, other countries would follow suit. It would also be in these countries' economic interest to avoid the implicit tax on assets and payroll that is embedded in a 
three-factor formula. ${ }^{14}$ This built-in incentive for sales-based formulas would minimize the likelihood of over or under-taxation due to disparate formulas, an obstacle to adopting formulary apportionment. Still, it would be ideal to have international cooperation and consensus regarding both the adoption of FA and the choice of formula. We will discuss below the problems that arise if only the US were to adopt FA, or if different countries use different formulas.

\section{Five Key Advantages to Formula Apportionment}

The first advantage associated with this proposal is that it would align the United States corporate tax system with the reality of a truly global world economy. In a world where most major corporations are multinational firms, where $70 \%$ of U.S. international trade is done by multinational firms, and where many opportunities for tax avoidance have an international dimension, the current U.S. system of corporate taxation is obsolete. In particular, separate accounting (SA) systems treat each affiliate of a multinational firm as a distinct entity with its own costs and incomes. Allocating income and expenses across countries is both complex (an issue discussed below) and conceptually unsatisfactory, given that worldwide income is generated by interactions between affiliates across countries. Multinational firms exist in large part because these interactions generate more income than would separate domestic firms interacting at arms-length; thus, requiring firms to allocate this additional income among domestic tax bases is necessarily artificial and arbitrary, because it would by definition disappear if the related entities operated at arm’s length. Further, such allocation generates ample

\footnotetext{
${ }^{14}$ In the last 50 years, over 100 countries have adopted the VAT, and every single one of them (including all other members of the OECD) has adopted the destination principle (i.e. imposing VAT on imports and rebating it on exports). The spread of destination-based VATs around the world provides a good example of how tax innovations can spread without a coordinating supra-national agency or "world tax organization,” simply on the basis of countries’ perception of their self-interest.
} 
opportunity for multinational firms to reduce worldwide tax burdens by shifting income to more lightly taxed jurisdictions, an issue that will be returned to below.

Under a FA system, tax liabilities are instead based on a multinational firm’s global income, and the share that is taxed by the national jurisdiction depends on the fraction of a firm's economic activity that occurs in a particular country. In the case of a sales based definition, the measure of economic activity is sales, which focuses on the demand side of market value. One could argue that a three-factor formula would also take into account the supply side of economic activity (with payroll and assets representing the capital and labor inputs into the production process), but we feel that the disadvantages of adopting a three-factor formula outweigh this conceptual advantage. ${ }^{15}$

Thus, while a truly precise definition and measurement of economic value is likely unattainable, FA provides a reasonable, administrable, and conceptually satisfying compromise that suits the nature of the global economy. Further, a FA system does not create an artificial legal distinction among types of firms, and whether multinational entities are organized as subsidiaries, branches, or hybrid entities. Nor does an FA system rely on an artificial distinction between MNEs whose parent is incorporated in the United States and MNEs whose parent is incorporated elsewhere. ${ }^{16}$

The second advantage associated with the proposal is that it eliminates the tax incentive to shift income to low-tax countries. As income shifting incentives are an important part of the overall tax incentive for locating operations in low-tax countries, removing this incentive will also result in less tax-distorted decisions regarding the

\footnotetext{
${ }^{15}$ See Appendix B for more discussion of alternative formulas.

${ }^{16}$ If a sales-based formula is adopted, both US and foreign-based MNEs would be able to locate their headquarters (which frequently produce positive externalities, such as those that flow from $R \& D$ ) in the United States without increasing their tax burden.
} 
location of economic activity. Under FA, firms are taxed based on their global income. Thus, accounting for the income earned in each country is no longer necessary, and there is no way to lighten global tax burdens by manipulating this accounting for tax purposes. Since the share of global income that is allocated to each country under FA depends on the share of a multinational firm's sales that are in each country, there would be some tax incentive to distort the location of sales among markets. However, this could be combated by basing the sales definition on a destination principle, and in general, firms have an incentive to encourage sales in each market in order to serve the customers there.

Under FA, there is no reason for the sort of profit distortions that are so clearly visible in Figure $2 .{ }^{17}$ In addition, when firms consider the tax advantages associated with operating in low-tax countries, these advantages will be based simply on the lower tax associated with their sales in such countries, rather than additional advantages conferred due to the fact that real operations in low-tax countries facilitate tax avoidance. Thus, the adoption of FA should vastly reduce tax distortions to multinational firm decision making. Also, it is important to note that, despite the emphasis on the sales of MNEs in different countries, this remains a corporate income tax, not a consumption tax. For example, tax liabilities do not arise unless a multinational firm is earning profits worldwide, irrespective of their sales.

Even though a unilateral move toward FA creates large incentives for other countries to adopt FA, and in particular sales-based formulas, such changes in the taxation of international income ultimately help governments set their tax policies more independently. The wishes of voters in each government influence the ideal size of government, required revenue needs, and the allocation of the tax burden among

\footnotetext{
${ }^{17}$ A very similar pattern is apparent in other years. The BEA data are discussed further in Appendix A.
} 
subgroups within society. Under FA, governments would be able to choose their own corporate tax rate based on their assessment of these sorts of policy goals, rather than the pressures of tax competition for an increasingly mobile capital income tax base.

The third advantage associated with the proposal is the massive increase in simplicity that this would enable for the international tax system. If FA were adopted by our major trading partners, simplification gains would be particularly large, but simplification would still exist even if FA was adopted unilaterally. To determine U.S. tax liability, there would be no need to allocate income or expenses among countries, resulting in far lighter compliance burden for firms. Subpart F and the foreign tax credit, which are both hugely complicated and a major source of transaction costs for US-based MNEs, are no longer necessary, since there is no deferral under this system (which is essentially territorial and treats US- and foreign-based MNEs alike).

Further, the likely administrative savings from abandoning the current cumbersome transfer pricing regime are huge. The current regime consumes a disproportionate share of both IRS and private sector resources. For example, several recent Ernst and Young surveys of multinational firms have concluded that "transfer pricing continues to be, and will remain, the most important international tax issue facing MNEs”. (Ernst and Young, 2006) 70\% of their respondents feel that transfer pricing documentation has become more important in recent years, and 63\% of respondents report transfer pricing audit activity in the previous three years. (Ernst and Young, 2005). For the government, audit costs are several (three to seven) times higher for 
federal transfer pricing cases than for state formula apportionment audits, even in the case where the most efficient federal cases are compared to the least efficient state ones. ${ }^{18}$ Opinions in transfer pricing cases run to hundreds of pages each, and litigation involves billions of dollars in proposed deficiencies, such as the recently settled Glaxo case ( $\$ 9$ billion in proposed deficiency, settled for $\$ 3.4$ billion) or the Aramco advantage case (litigated and lost by the IRS, which asserted deficiencies of over $\$ 9$ billion). There is no indication that the 1994 regulations under IRC section 482 have abated this trend (Avi-Yonah, 2006). While there have been fewer decided cases than under the pre-1994 regulations, this is because both taxpayers and the IRS have been devoting enormous resources to settling these controversies in the appeals process, in litigation or through advance pricing agreements, while both sides have been wary of losing a major court case.

The contemporaneous documentation rule adopted by Congress, which requires taxpayers to develop documentation of their transfer pricing methods at the time the transactions are undertaken rather than when they are challenged on audit, as well as the complexity of the new SA methods (such as the Comparable Profits Method, or CPM), have led the major accounting firms to develop huge databases and expertise in preparing transfer pricing documentation for clients. This imposes large costs on major US multinational corporations (Durst and Culbertson, 2003). Meanwhile, small and medium businesses, which cannot afford the major accounting firms, are left to fend for themselves and are frequently targeted for audits in which the IRS can employ more sophisticated methods than the taxpayer because only the IRS and the large accounting firms have the necessary data to apply CPM. Thus, while the IRS continues to lose

\footnotetext{
${ }^{18}$ See Bucks and Mazerov (1993).
} 
transfer prices cases against major MNEs under the 1994 regulations (e.g., Xilinx) or has to settle for less than half the proposed deficiency in Glaxo, it is able to win cases against small and medium firms on the basis of superior resources, rather than greater substantive justification of its position.

By contrast, FA is relatively simple since all that it requires is (1) establishing which businesses are unitary (discussed below) and (2) establishing destination of arm'slength sales of goods or services. Once these two elements are established, the resulting formula permits both taxpayers and the IRS to determine to correct tax liability to each jurisdiction that uses FA. This means that there is no longer a need to allocate or apportion expenses (a source of major complexity in the current rules, as the 861 regulations indicate), because all a business needs is to calculate its world-wide net income (worldwide gross income minus worldwide expenses). This net income is then allocated to various jurisdictions based on a single formula, the tax rate of each jurisdiction is applied to the allocated income, and the tax is paid.

For small and medium businesses in particular, FA results in major cost savings as well as the likelihood of paying less tax (since such businesses are rarely in a position to take on the IRS under SA). For major multinational firms, FA also offers the prospect of avoiding the costs of contemporaneous documentation, and while some firms may pay more tax than under SA, many would welcome the opportunity of paying a single, low rate to each jurisdiction they do business in (especially if the adoption of FA is coupled with a reduction in the corporate rate), instead of having to cope with the complexities and costs of SA. Of course, some firms will also be hurt by the change in tax environment; these issues are discussed below, at the end of Section IV. 
The fourth advantage associated with the adoption of FA for the United States is that the new system would either raise more revenue or enable a substantial rate reduction. Estimating exactly how much revenue such a change would raise is a difficult and imprecise task, and the details of the implementing legislation and regulations would likely be influential in determining the ultimate effects of the proposed change. Still, previous studies and back-of-the-envelope calculations suggest that such a change is likely to generate substantial additional U.S. government revenue.

Appendix A reviews several such calculations in more detail. For example, one recent study finds that tax avoidance activities reduce income earned in the United States by U.S. multinational firms by over $\$ 150$ billion in 2002, resulting in corporate tax revenues that are about 35\% lower. Since FA would eliminate tax avoidance incentives, one would expect it to raise revenues by a similar margin.

The most thorough estimate to date is Shackleford and Slemrod (1998); they use accounting data in financial reports for 46 U.S. based multinational corporations over the period 1989 to 1993 to estimate changes in revenue under a three-factor FA system. They find that U.S. government revenues would increase by 38\%. This increase is not dependent on any particular factor, and they calculate that a single factor sales formula would increase revenues by $26 \%$. Given the changes in the international tax environment since the time period of their data, and in particular the increasing discrepancy between the U.S. corporate tax rate and those of other major countries, these estimates likely understate the current U.S. revenue gain with FA adoption.

Table 1 shows illustrative statistics on the operations of U.S. multinational affiliates in 2003 for all countries where the Bureau of Economic Analysis reports data 
and where affiliate operations are at least one half of one percent of world-wide totals in either sales or income. Column (1) shows the share of worldwide foreign affiliate sales that occur in each country, column (2) shows the share of worldwide affiliate net income earned in each country, column (3) shows the effective tax rate, and column (4) shows the percentage by which the income share exceeds or falls short of the sales share. Countries are shown in the descending order of values for column (4), and it is immediately apparent that those countries with income shares that vastly exceed their sales shares tend to be very low-tax countries, and those with sales shares that exceed their income shares are typically high-tax countries. Thus, it appears quite likely that a sales-based formula apportionment system would increase revenues in comparatively high-tax countries, decreasing them in low-tax countries.

As one plausible conjecture, if revenues increase by 35\% with formula apportionment, one can also calculate the tax rate reduction that would be possible with a revenue-neutral implementation of FA. In that case, the implied new corporate tax rate would be $26 \%$, nine percentage points lower than the current corporate tax rate of $35 \%$. Of course, one could also pursue an intermediate policy that allowed a smaller rate reduction and also increased revenues more modestly. Appendix A provides more background on these calculations.

Therefore, adoption of FA can help address the four flaws in the current system of U.S. taxation that were discussed in Section II of the paper. There are also potential gains due to coordination with other taxes as well as coordination among countries. Consider first coordination with value added taxes. Existing VATs around the world depend of defining the destination of sales of goods and services. Determining 
destination for goods is relatively easy because of customs enforcement. In fact, many jurisdictions use harmonized rules for customs, VAT and income tax collection. Determining destination for services is harder, but countries have developed significant expertise in it under VAT. If the United States adopts sales-based FA, it can learn from this experience even without adopting its own VAT. If the US subsequently adopts a VAT, the existing rules for determining sales destination under FA can be coordinated with the VAT rules. In addition, existing US regulations already define destination and origin of goods for purposes of trade regimes, tax-based export subsidies, and under the base company rules of Subpart F, and any FA regime can build on this expertise as well. This proposal also introduces the possibility of gains from coordination with other countries. The EU Commission is actively working on defining a common tax base and apportioning it among member states by formula. ${ }^{19}$ We can learn from this effort (which itself learned from the US state and Canadian province experiences). ${ }^{20}$ Also, if the United States and the European Union both adopt FA, there is obvious potential for coordinating their efforts through the OECD. It may in fact be possible, given current discussions of FA within the EU, to reach agreement with the EU (and possibly with other OECD members) on the adoption of FA before it is actually implemented.

Still, while an international agreement would be ideal, we do not believe that reaching such an agreement should be a necessary prerequisite to the United States adopting FA unilaterally. Many significant advances in international taxation, such as the

\footnotetext{
19 Gnaedinger and Nadal (2007) report that EU Tax Commissioner Kovacs is optimistic that the common consolidated corporate tax base would move forward, despite the opposition of a minority of EU member governments. If a member country vetoes the draft legislation, the EU may turn to the "enhanced cooperation procedure” through which action can still proceed. Kovacs described a timeline through which the common tax base could be in place as soon as 2010 .

${ }^{20}$ See Weiner (2005).
} 
foreign tax credit and CFC regimes, as well as more problematic developments such as the current transfer pricing methods, resulted from unilateral action by the United States, which was followed by most other jurisdictions and by the OECD.

\section{Downsides of Formulary Apportionment}

This section of the paper will consider potential drawbacks associated with this proposal. The concerns fit into four broad categories. First, some critics argue that FA is inherently arbitrary. Second, there are implementation issues associated with the definition of a unitary business and the determination of the location of sales. Third, there are problems associated with interactions between countries with incongruent corporate tax systems. There is a potential for zero or double taxation, accounting standards across countries are not uniform, tax treaties may need modification, revenues may systematically shift away from some countries, and there may be issues of compatibility with WTO obligations. Finally, the proposed FA system is likely to negatively impact some stakeholders, as some domestic industries and firms will find that their tax obligations increase under the new system.

\section{Is Formulary Apportionment Arbitrary?}

Some would consider basing the corporate income tax liability solely on the extent of sales in a particular country to be arbitrary. Indeed, this approach focuses on the demand side of the value created by the corporation. For example, the market jurisdiction would levy the entire corporate income tax in the case of a MNE that produces in one country and sells in another. Still, it is not clear that the current SA regime is less arbitrary given the incentive to shift profits to low-tax jurisdictions. 
Under the current regime, it is quite possible that a MNE will not pay taxes either in the location of production (because of tax competition and production tax havens) or in the location of distribution (because it can avoid having a permanent establishment or minimize the profits attributable to the distribution function), while any tax due to its residence jurisdiction are subject to deferral or exemption. Such a result is more arbitrary than consistently assigning profits to the market jurisdiction, especially if most countries adopt the same formula. ${ }^{21}$

It is true that any formula can produce arbitrary results in a given industry. For example, the oil industry has long argued that it is unfair to tax it based on payroll, assets or sales because most of its profits result from the oil reserves themselves, which are not reflected in the formula (since they are typically not assets of the company for any length of time). However, while some industries will lose under the proposed formula, others (such as major US exporters) will win, and most taxpayers would gain from the increased simplicity and transparency of the FA regime. If companies are willing to pay one level of tax and are only concerned about double taxation, they should be willing to accept the FA option, which prevents double taxation but also double non-taxation. ${ }^{22}$

\section{Implementation Issues}

\section{Defining a Unitary Business and the Destination of Sales}

\footnotetext{
${ }^{21}$ In fact, it is likely that a high proportion of current corporate tax collections come from taxing distribution activities that rise over the permanent establishment threshold (or are conducted in a separate subsidiary), given the ubiquity of targeted tax incentives for production activities. This explains why there is so much current pressure on the definition of permanent establishment (LeGall, 2006). Thus, other than reducing distortions, our proposal is a less radical shift from current reality than it appears to be from a theoretical perspective.

22 It can also be argued that ignoring intangible property, which is the source of most of the value added by MNEs, is arbitrary under both our formula and the state formulas (that do not include intangibles in the property factor). But intangibles do not have a real location, and their value inheres in the whole MNE, which is why they cannot be adequately addressed under SA. Any formula that ignores intangibles assigns their value to the entire MNE (divided based on the other factors used in the formula), and we believe this result more accurately reflects the nature of intangibles.
} 
First, a difficult implementation issue in adopting FA is how to define a unitary business. Current IRC 482 (implementing SA) merely requires direct or indirect control among related parties, without even a precise definition of what control requires such as is found in other IRC provisions. However, for purposes of FA, mere control is not enough since in the absence of unitary business activities (i.e., an integrated MNE), FA can lead to significant distortions in the way a business operates (lumping together disparate sales from different businesses). In addition, relying solely on control would violate tax treaties that require something more for a subsidiary to be an agent of the parent.

We would suggest a test of unitary business that depends on whether the subsidiary in fact operates under the legal and economic control of the parent. ${ }^{23}$ Such a test would look at factors like where overall business strategy is set, the extent to which risk of loss is shared, and the extent to which there are transfers of goods and services among the constituent units of a MNE. In most modern MNEs, the level of integration is sufficient to find a unitary business, as the experience of the states in administering this test has shown. About $40 \%$ of all U.S. international trade takes place between affiliates of MNEs, suggesting the extent to which they are integrated. Moreover, the underlying transfer pricing problem depends on transactions among constituent parts of an MNE, so relying on such transactions as the basis for finding that a unitary business exists is appropriate to address the problem. ${ }^{24}$ Imposing a rebuttable presumption of control

\footnotetext{
${ }^{23}$ This definition tracks the requirement for finding that a subsidiary is a dependent agent of the parent under tax treaties, discussed below.

${ }^{24}$ If a MNE has several lines of business that are truly not related to each other (e.g., GE's financial and non-financial businesses), FA should be implemented for each one separately. While this raises some definitional issues as well as the possibility of having to apply SA-based transfer pricing to any transactions between such lines of business, these problems should be far narrower in scope than those raised by the current system.
} 
whenever there is a combination of legal control (i.e., ownership of over $50 \%$ of the stock by vote or value, with the usual attribution rules) plus some de minimis level of interMNE transactions should go a long way to prevent tax-motivated attempts to break control.

While it is possible that taxpayer may try to avoid taxation by using “independent” distributing agents for their sales, it is unlikely that they would be willing to relinquish real control over their marketing and distribution activities, since that is why they are organized in MNE form in the first place (otherwise they could begin operations in a foreign country by selling through independent distributors, which is usually less costly). In addition, we would adopt a look-through rule that would regard any sales made by a MNE to an unrelated distributor as sales made into the U.S. if the distributor in fact sells the goods into the U.S. and does not substantially transform them before they are resold. ${ }^{25}$ This would prevent MNE from avoiding tax by selling their goods into the U.S. via unrelated “strawmen” who would themselves have minimal profits. ${ }^{26}$

Second, implementing a sales-based formula depends on the ability of tax administration to determine the destination of sales of goods and services. This issue also arises under VATs and state income and sales taxes. In general, for a country like the US that maintains customs controls, establishing the destination of goods is not a significant problem, and is already the basis of several Internal Revenue Code provisions. ${ }^{27}$ The destination of services poses more difficult issues, but these problems

\footnotetext{
25 The substantial transformation test can be based on current Treas. Regs. 1.954-3(a)(4).

26 Since we ignore intra- MNE sales, the MNE cannot engage in "round tripping" transactions in which it exports goods and then re-imports them into the U.S.

27 See, e.g., Treas. Reg. 1.954-3(a)(3) (the base company sales rule), as well as the various export-related rules (IRC secs. 941-943, 970-971, 991-994), all of which rely on establishing the destination of goods sold.
} 
also arise under a VAT and have in general been treated successfully. For business to business provision of services (which covers the majority of services to unrelated parties), a rule that the destination of services is the jurisdiction in which the receiving business takes a deduction for payment to the service provider should establish the destination of the service.

\section{Interactions Between Countries with Different Tax Systems}

It would be ideal for most major countries to coordinate implementation of FA and to come to a joint agreement on the definition of the formula for apportioning global income. Given that the European Union (EU) is already pursuing the possibility of FA within Europe, a natural forum for reaching international consensus on these issues would be the OECD. With international cooperation, the possibility of double or nontaxation would be reduced and there would be less room for multinational firms to respond strategically to variations in country formulas.

Moreover, one should note that unilateral adoption by the United States of a formula apportionment (FA) system for taxing international income would create a powerful incentive for other countries using separate accounting (SA) to also adopt FA. In a world with both FA and SA system countries, FA countries will immediately appear as tax havens from a SA country perspective. For example, a multinational firm operating in SA and FA countries would have an incentive to book all their income in FA countries, as the tax liability in such countries does not depend on the income booked there, but rather the fraction of a firm's activities in that location. Such responses would likely greatly reduce the tax revenues of remaining SA countries. Thus, SA countries will have a strong incentive to adopt FA, particularly if large economies adopt FA. 
Moreover, the experience of the U.S. states amending their formulas to emphasize the sales factor, and the experience of over 100 countries adopting the destination-based VAT, suggests that there is a significant likelihood that if the U.S. were to adopt a salesbased formula, other countries would be inclined to follow suit. The U.S. led the way in adopting the foreign tax credit (1918), Subpart F (1962), and the current transfer pricing regulations (1968 and 1994), all of which were followed by most of our major trading partners and recognized by the OECD. It is quite possible that if the U.S. adopted salesbased FA, this would be another innovation that is widely copied, with or without explicit coordination.

Still, if the United States adopts FA unilaterally and other countries do not follow suit (or follow suit much later), or if countries adopt different formulas, there is the potential for double or zero taxation. This is the largest obstacle to adoption of FA. As argued above, there are built-in incentives for countries to respond to the other countries' adoption of FA by themselves adopting FA, and there are also built-in incentives to move toward sales based formulas. These incentives might help promote international cooperation in the initial negotiations regarding adoption and formula determination. Still, absent foreign adoption, problems of double or non-taxation may be particularly worrisome.

Further, even if other countries eventually adopt FA, there will likely be a transition period while governments and multinational firms adapt to the new tax environment. During this transition period, there may be problematic instances of double-taxation, and the firms that experience increased tax liabilities under FA may prove to be vocal critics of FA. 
While situations of double taxation could arise, it is not clear that FA would produce more double taxation or double non-taxation that the current SA regime. As noted above, there is significant evidence that the SA regime results in under-taxation as MNEs succeed in shifting profits from high-tax to low-tax jurisdictions. However, SA can also result in double taxation to the extent that a high-tax jurisdiction successfully asserts that profits belong to it and not to another high-tax jurisdiction.

For example, the IRS recently settled a major transfer pricing case with the British firm Glaxo for \$3.4 billion. This additional revenue resulted from shifting to the US profits that Glaxo claimed belonged in the UK. It is far from clear that the UK tax authorities would accept the result of this settlement: Under the US-UK tax treaty, they are not required to do so. (Art. 9 of the treaty only states that a country must make a “correlative adjustment” when profits are shifted by the other treaty partner if it agrees that the profit shift was justified, which the UK seems unlikely to accept.) The dispute resolution mechanism in most of our tax treaties does not provide for binding arbitration and therefore does not necessarily lead to a resolution. As Justice Brennan observed in the Container case (approving California’s application of worldwide FA to US-based MNEs), it is not clear which method (FA or SA) produces more over- or under-taxation, even when some countries use FA and the others use SA, or when different formulas are used.

Fundamentally, the issue of double or under-taxation under SA and FA resolves to the incentives facing taxpayers and governments, and whether taxpayers or governments are better positioned to respond to such incentives. Under SA, taxpayers are able to achieve under-taxation by shifting profits to low tax locations, and governments 
have an incentive to prevent that, but forty years of experience have shown that governments are slow, and that the SA rules are insufficient to deter taxpayers or to enable governments to collect the corporate tax due. Under a combination of FA and SA, double taxation can result, but the incentive is for the taxpayers to prevent that by shifting profits out of SA countries into FA countries, which will in turn incentivize governments to adopt FA. Finally, under FA double taxation can result if different countries have different formulas, but taxpayers can prevent it by shifting production factors out of countries that have production factor-based formulas. Since taxpayers are more nimble than governments, it would seem preferable if the goal is to prevent over- or undertaxation to err on the side of temporary double taxation, which can be remedied by taxpayer action, rather than rely on governments to prevent under-taxation.

\section{Defining the Tax Base}

There are issues associated with the need for common accounting standards. Still, the unilateral adoption of FA by the United States need not require the US and other countries to have a common tax base. However, as noted above, the ideal situation would be for most countries to adopt FA using the same (sales-based) formula. For this purpose, a common definition of the tax base is needed, as currently advocated by the EU Commission.

Such a common definition of the tax base (as opposed to harmonized tax rates, which are unlikely as well as undesirable) is plausible to achieve because MNEs already use uniform accounting for world-wide financial reporting purposes. Thus, it is quite possible to use financial reporting as the starting point for calculating the global profit of the MNE, to be allocated to jurisdictions based on the FA formula. While there are still 
differences in accounting among countries, those are diminishing due to the spread of International Accounting Standards, which have been adopted in the EU and Japan. Alternatively, it may be possible to let each MNE use its home country accounting methods for calculating the global tax base (as suggested by the EU Commission for inter-EU purposes). In that case, US MNEs would be able to use US GAAP for tax reporting in the EU and Japan, rather than incurring the cost of producing two sets of financial reports under GAAP and IAS. Many European MNEs support FA in the European Union precisely because of the cost savings involved.

Such changes would also have the advantage of more closely aligning book income and tax income. This could act a damper on both the underreporting of income for tax purposes as well as the overstatement of income for the purpose of signaling profitability to financial markets. $^{28}$

However, if coordination of the tax base with accounting-based measures were unachievable or undesirable, FA could also be implemented unilaterally by the U.S. using its definition of taxable income and applying it to the entire MNE. U.S.-based MNEs already have to calculate the earnings and profits of CFCs for purposes of Subpart F and the foreign tax credit, so the additional information required for unilateral adoption would not be over-burdensome. For non-U.S. based MNEs, we could use financial reporting to shareholders (already required by the SEC or by home country regulators) as the base for calculating worldwide income. While this would create a disparity between U.S. and non-

\footnotetext{
${ }^{28}$ This is discussed in Desai (2005), where he recommends reconsideration of the dual-reporting system. Desai (2003) reports an increasing divergence between book income and tax income, with more than half of the divergence not explained by conventional differences between the measures. For the United States in 1998, he estimates that this discrepancy amounts to about 34\% of tax income (just over $\$ 150$ billion), and he attributes these trends to increased tax sheltering activities.
} 
U.S. based MNEs, the result is similar to allowing MNEs to use their home state base for tax purposes, as recommended by the EU.

\section{Interaction with Tax Treaties}

Some have argued that tax treaties will need modification with adoption of formulary apportionment. However, it is not clear that existing US tax treaties will have to be renegotiated. Transfer pricing is currently governed by Article 9 of the treaties, which assumes the SA method because it addresses the commercial or financial relations between associated enterprises. If FA were adopted, Article 9 would become irrelevant in those situations to which FA applies (i.e., where a unitary business is found to exist) because FA ignores the transactions between related parties, and treats them instead as part of a single enterprise.

Instead, FA would be governed by Article 7, which governs the relationship between a parent company and a branch (permanent establishment) or an agent. Under Article 5(7), “[t]he fact that a company that is a resident of a Contracting State controls or is controlled by a company that is a resident of the other Contracting State ... shall not constitute either company a permanent establishment of the other.” However, it is well established that a dependent agent can be a permanent establishment (see Art. 5(5)), and whether an agent is dependent is based on whether the principal exercises legal and economic control over the agent. "An agent that is subject to detailed instructions regarding the conduct of its operations or comprehensive control by the enterprise is not legally independent.,29

\footnotetext{
${ }^{29}$ U.S. Treasury (2006), Art. 5(6).
} 
In the case of a modern, integrated MNE that operates as a unitary business, a strong argument can be made that the parent of the MNE exercises both legal and economic control over the operations of the subsidiaries, especially where the subsidiaries bear no real risk of loss and acquire goods and services exclusively or near exclusively from the parent or other related corporations. In that case, the subsidiaries should be regarded as dependent agents of the parent. Such a finding is in fact made with increasing frequency. (See LeGall’s (2006) discussion of recent cases from Germany, Italy and Canada, as well as from developing countries, and the Inverworld case in the US).

If the subsidiary is an agent of the parent, Art. 7(2) of the treaties requires the attribution of the same profits to the subsidiary "that it might be expected to make if it were a distinct and independent enterprise engaged in the same or similar activities under the same or similar conditions.” Arguably, the application of FA, even when based on a sales only formula, satisfies this arm's length condition because in the absence of precise comparables (which almost never exist) it is not possible to determine exactly what profits would have been attributable to the subsidiary under SA.

When the US adopted CPM and profit split in the 1994 transfer pricing regulations, some countries objected that it was violating the treaties because these methods did not rely on exact comparables to find the arm's length price. However, these objections soon subsided, and even the OECD endorsed similar methods in its transfer pricing guidelines. The US always maintained that both CPM and profit split satisfy the arm's length standard despite the lack of precise comparables (and in the case of profit split, using no comparables at all to allocate any residual profits). Similarly, the US has 
maintained that the "super-royalty rule" of IRC sec. 482 (which requires royalties to be "commensurate with the income" from an intangible, and therefore subject to periodic adjustment) is consistent with the arm's length standard, even though no comparables can be found to show that such adjustments are ever made by unrelated parties.

Thus, were the US to adopt FA, it could similarly argue that the resulting allocation of profits to the subsidiary is consistent with the arm's length standard embodied in articles 7 and 9. Despite the OECD’s traditional hostility to FA, there is no way to prove in the absence of comparables that any profit allocation deviates from an arm’s length result. As stated in 1993 by senior officials of the United States Treasury, the United Kingdom Inland Revenue, the Fiscal Affairs Division of the OECD and the Japanese National Tax Administration:

“[T]he arm's length principle and formulary apportionment should not be seen as polar extremes; rather, they should be viewed as part of a continuum of methods ranging from CUP to predetermined formulas. It is not clear where the arm's length principle ceases and formulary apportionment begins, and it is counterproductive and unimportant to attempt to apply labels to the methods." 30

Nevertheless, although the adoption of FA would not require renegotiating any

US treaties, it would be a good idea for the US to explicitly sanction the use of FA in future treaty negotiations. This can be done by inserting in future US treaties the language of OECD Model Art. 7(4):

"Insofar as it has been customary in a Contracting State to determine the profits to be attributed to a permanent establishment on the basis of an apportionment of the total profits of the enterprise to its various parts, nothing in paragraph 2 shall preclude that Contracting State from determining the profits to be taxed by such an apportionment as may be necessary; the method of apportionment adopted shall, however, be such that the result shall be in accordance with the principles contained in this Article."

\footnotetext{
${ }^{30}$ Arnold and McDonnell (1993).
} 
This language is found in many existing tax treaties based on the OECD and UN models, and it can be used by the US as a basis for applying FA without resort to a treaty override.

There is one situation where existing treaties would prohibit application of FA based on sales, which is when a corporation is able to sell goods or provide services to a market without any kind of permanent establishment, directly or through an agent. This situation can arise in some cases of electronic commerce. ${ }^{31}$ However, the same problem arises also under SA, and countries in general have been able to avoid significant revenue losses by aggressive interpretation of the permanent establishment threshold, and because it is difficult as a business matter in most situations to avoid having any presence in the market jurisdiction. In the long run, we would support renegotiating the treaties to incorporate a modernized version of permanent establishment that does not depend on physical presence but rather on the volume of sales into a market jurisdiction, as is commonly done for VAT purposes (most VAT jurisdictions have de minimis rules for volume of sales).

\section{Distributional Issues}

Revenues may systematically shift away from some countries under formulary apportionment. The current tax haven countries would likely experience large reductions in revenues. For example, Ireland and Luxembourg are both low-tax countries where disproportionate amounts of corporate income is earned, and in 2002, Ireland received 3.8\% of GDP from the corporate tax and Luxembourg received 6.2\% of GDP, both well above the OECD average revenue share of $2.9 \%$.

\footnotetext{
31 See, e.g., the recent state case involving MBNA, which applied an “economic nexus” theory in the absence of any physical nexus.
} 
Also, some have argued that a sales-based formula would benefit countries like the United States, which runs a large trade deficit, at the expense of countries with large trade surpluses. However, the key determinant of which countries would gain or lose revenue is whether countries have disproportionately large or small amounts of local corporate sales relative to corporate income. And, there is no evidence in the data that this factor is related to countries’ trade positions.

If one considers the operations of U.S. multinational firms and their foreign affiliates as a guide, it is quickly apparent that it is difficult to make regional generalizations about which countries will gain or lose. For example, developing countries do not have systematically lower (or higher) levels of local affiliate sales relative to affiliate income in comparison with richer countries. It appears, for example, that the ratio of local sales to corporate income for U.S. affiliates in African countries is quite similar to the world average. Asian and Latin American countries actually have a higher ratio of local sales to corporate income than the world average, whereas European countries have a slightly lower ratio of local sales to corporate income. In all cases, however, regional averages mask significant differences across countries. In general, high-tax countries would likely gain revenue at the expense of low-tax countries following the adoption of FA, as high tax countries tend to have higher shares of local corporate sales relative to corporate income.

This conclusion assumes widespread adoption of FA; absent that, the remaining SA countries would also lose revenue as MNEs would have a strong incentive to book income in FA countries, since their tax liabilities in such countries would not be affected by this accounting. Still, despite concerns about systematic revenue losses to some 
countries, we believe that our proposal will eventually help many governments by eliminating incentives for tax competition.

\section{Interaction with WTO Rules}

Finally, some scholars have argued that the use of a sales-only formula by US states violates WTO rules against export subsidies, because they constitute an illegal border adjustment for direct taxes. In general, the WTO rules permit border adjustability for indirect taxes, but not for direct taxes. Although this line has been widely criticized as incoherent, it is embedded in the current WTO agreements.

It is not clear that the adoption of a federal sales-only formula for income taxes would in fact be a WTO violation. It can be argued that the formula is not explicitly contingent on export performance, and that it only serves as a means for allocating the income tax base among jurisdictions, as opposed to exempting transactions that would otherwise be taxable (as in a VAT). No WTO complaint has in fact been filed against the US on the state formulas, even though state taxes are subject to WTO constraints.

Also, if the adoption of FA by the United States occurs alongside widespread adoptions at least among OECD member countries, it would seem plausible that the WTO rules (which are widely regarded as obsolete) can be renegotiated. In general, progress in the WTO is usually impeded if the US and other OECD members disagree (e.g., on agricultural subsidies), but not if they agree. As noted above, the EU Commission has already endorsed FA, and thus a challenge by the European Union is unlikely.

If a country does successfully challenge the US over the adoption of sales-based FA, and the rules cannot be renegotiated, this might require changing the formula to one 
based equally on assets and sales, which is not open to WTO challenges. However, this would come at a price of encouraging more artificial shifting of assets to low-tax jurisdictions, so we do not advocate it at present.

\section{Negative Effects on Some Corporate Stakeholders}

Analysts have noted that adoption of FA would disproportionately affect some industries and firms negatively. For example, Shackelford and Slemrod (1998) find that FA raises tax liabilities for some industries and firms, lowering burdens for others. They estimate that the oil and gas industry would see an increase in tax liabilities of $81 \%$ under FA, compared with 29\% for all other firms in their study. (The mean oil and gas company in their study reports $68 \%$ of assets in the United States, $70 \%$ of sales in the United States, and 78\% of total compensation paid to U.S. employees, but such companies book $42 \%$ of pretax earnings in the United States.) The authors also estimate that some firms will experience a tax decrease, including Boeing, Procter and Gamble, and Dow Chemical.

Under our proposal, firms with a disproportionate amount of U.S. sales relative to U.S. income would see tax increases under FA, while those with relatively low U.S. sales compared to U.S. income (e.g., large exporters) would see tax decreases. In addition, observers such as Durst (2007) note that intangible-intensive firms would likely be adversely affected by adoption of FA, as these firms have been particularly adept at lowering their tax burdens through careful tax planning under the current system.

Still, negative impacts could be muted by several considerations. First, firms will benefit from reductions in complexity and compliance burdens. Small and medium size businesses should be particularly appreciative of such benefits. Second, if FA is 
accompanied by a reduction in the corporate income tax rate, which could prove quite substantial if FA is implemented in a revenue-neutral fashion, that would increase the number of firms benefiting from the adoption of FA. A rate reduction would also appeal to those concerned that the US is losing competitiveness because of the current rate disparity.

\section{Conclusion}

Our proposal for the adoption of formulary apportionment for the U.S. taxation of corporate income responds to the reality of an increasingly global world. Multinational firms have internationally integrated operations, and they are responsive to the incentives created by discrepancies among national tax policies. A separate accounting system generates an artificial need to assign income and expenses by location, and this creates ample opportunities for tax avoidance.

A formulary apportionment system would remove the complexities associated with sourcing income and expenses across locations, and it would eliminate the tax incentive to shift income to more lightly-taxed locations. Absent tax incentives to shift income away from the United States, U.S corporate tax revenues would likely increase significantly. If this proposal were implemented in a revenue neutral fashion, on the other hand, the corporate tax rate could be cut substantially. Even a revenue-neutral implementation of FA would retain the simplicity and efficiency gains associated with the proposal.

The common objections to FA appear surmountable. We have argued that the FA system is less arbitrary than the current system and that implementation issues can be 
overcome. While it would be ideal to implement FA with international cooperation, there are also natural incentives within a FA system that encourage international adoption and formula harmonization. Even absent international cooperation, problems of double taxation or double non-taxation need not be any larger than under the current SA system. Further, it is likely that FA would be compatible with current treaty and WTO obligations.

We also maintain that U.S. adoption of FA would be preferable to the other suggested reforms. First, consider a simple base-broadening, rate-lowering reform. This would no doubt be an improvement relative to the status quo as a lower rate would reduce the tax incentive to earn income in foreign countries and other distortionary effects of the current tax system. In addition, base-broadening would level the playing field among different corporate activities, reducing the deadweight loss associated with tax-induced modifications in financial or real behavior. ${ }^{32}$ Yet, while such a reform would be desirable relative to the status quo, it would fall short of the gains from Formulary Apportionment in terms of compatibility with the global economy, administrative simplicity, and the efficiency gains associated with eliminating income shifting incentives.

Second, consider the "Simplified Income Tax Plan" suggested by the President's Tax Reform Panel. This plan would adopt a territorial system for U.S. multinational corporations, exempting foreign income of U.S. firms from taxation. The report notes that this plan would create:

\footnotetext{
${ }^{32}$ As just one example, the production income deduction in the recent American Jobs Creation Act creates an artificial incentive to engage in production activity or to relabel income as production income; eliminating such provisions would be beneficial to broader integrity of the tax system.
} 
"more even treatment of cross-border investment by U.S. multinational corporations. Under the new system, territorial taxation of active foreign income would be available to all U.S. multinational corporations, not just those that are able to 'self-help' themselves to this result or its functional equivalent. The new system is designed to make U.S. businesses more competitive in their foreign operations, while reducing the extent to which tax planning allows some multinationals to achieve more favorable results than others.”33

Unfortunately, this proposal worsens many of the problems discussed above. In particular, firms would have an even larger incentive to shift income to low-tax locations. Further, while a territorial system could be designed to be revenue-neutral, the past experience of OECD countries suggests that territorial systems raise less corporate revenue. ${ }^{34}$ In addition, there would be limited simplification gains in comparison with FA, as multinational firms would still be responsible for sourcing income and expenses across locations, and the territorial nature of the tax system would put even greater pressure on the transfer pricing rules, as the report itself notes. ${ }^{35}$ We would in fact argue that adopting FA is the only way to achieve territoriality for US-based MNEs without risking significant revenue losses, worsening income shifting incentives, and increasing the complexity of the U.S. international tax regime.

Third, compare adoption of FA to a proposal that would simply end deferral of taxation on foreign income for U.S. multinational firms. One such proposal is discussed in Altshuler and Grubert (2006), as a “burden neutral worldwide taxation” plan. Under this plan, all foreign income would be taxed currently, there would be no required allocation of expenses to foreign income, and at the same time the U.S. corporate tax rate would be lowered so as to keep the overall U.S. tax burden on foreign income the same.

\footnotetext{
33 See chapter 5 of President's Tax Reform Panel report, page 105.

${ }^{34}$ See Clausing (2007a).

35 The Tax Reform Panel also suggested a "Growth and Investment Tax Plan” that would use domestic consumption as a tax base. While this plan has intriguing elements, it also raises broader issues than can be addressed in the scope of this paper.
} 
This system would effectively end deferral for U.S. resident corporations, and thus dramatically reduce income shifting incentives. The authors estimate that a burdenneutral implementation of the proposal would entail a corporate tax rate reduction on foreign income to $28 \%$. $^{36}$

Still, under their plan, income shifting incentives would not be completely eliminated, as foreign-based multinational firms would be largely unaffected. This consideration could create a stronger tax incentive for changing ownership patterns. For example, firms could undertake inversions, basing their parent company in a tax haven. In addition, income shifting incentives still exist for U.S. multinational firms with excess credits. $^{37}$

While all of these proposals have merits, they also illustrate the difficulties associated with the taxation of multinational firms in a globally integrated economy. It is nearly impossible to eliminate the tax distortions associated with the location of economic activity and profits across national boundaries without a dramatic rethinking of the nature of corporate income taxation in the world economy. We hope that this proposal contributes to that deliberation.

\footnotetext{
${ }^{36}$ Their estimates are based on tax return data for U.S. multinational firms from the Treasury Department. The estimates are "static estimates" that do not account for behavioral responses such as changes in income shifting behavior or reduced incentives to lower foreign taxes.

${ }^{37}$ The authors estimate that about $30 \%$ of foreign income would be earned by U.S. firms with excess credits under their plan. For firms with excess credits, there would still be tax planning opportunities associated with moving income from high-tax to low-tax countries, and with shifting income out of the United States.
} 
Figure 1, Panel A: Statutory Corporate Tax Rates, OECD Countries, 1979-2004

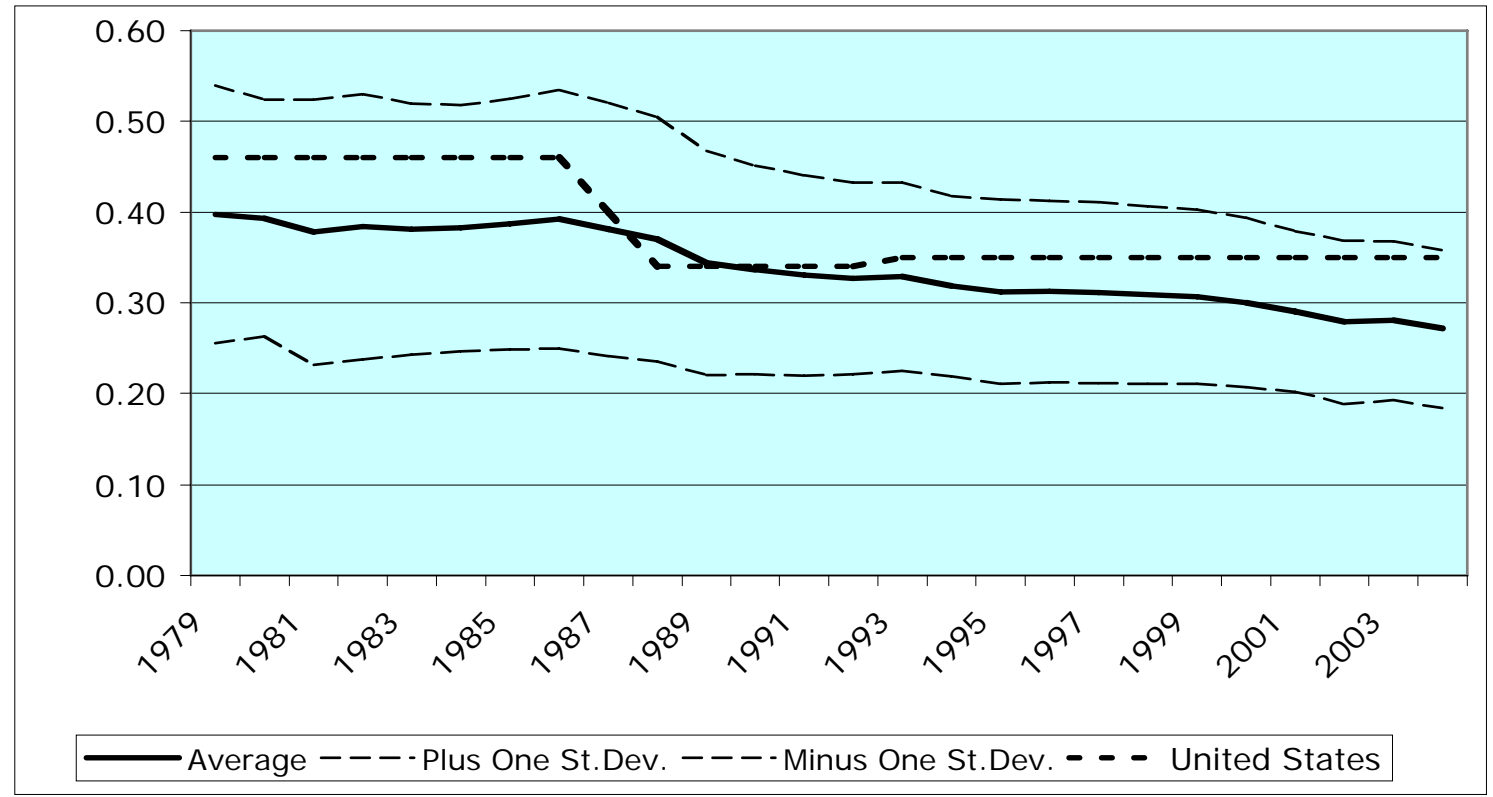

\section{Panel B: Average Effective Tax Rates, OECD Countries, 1982-2004}

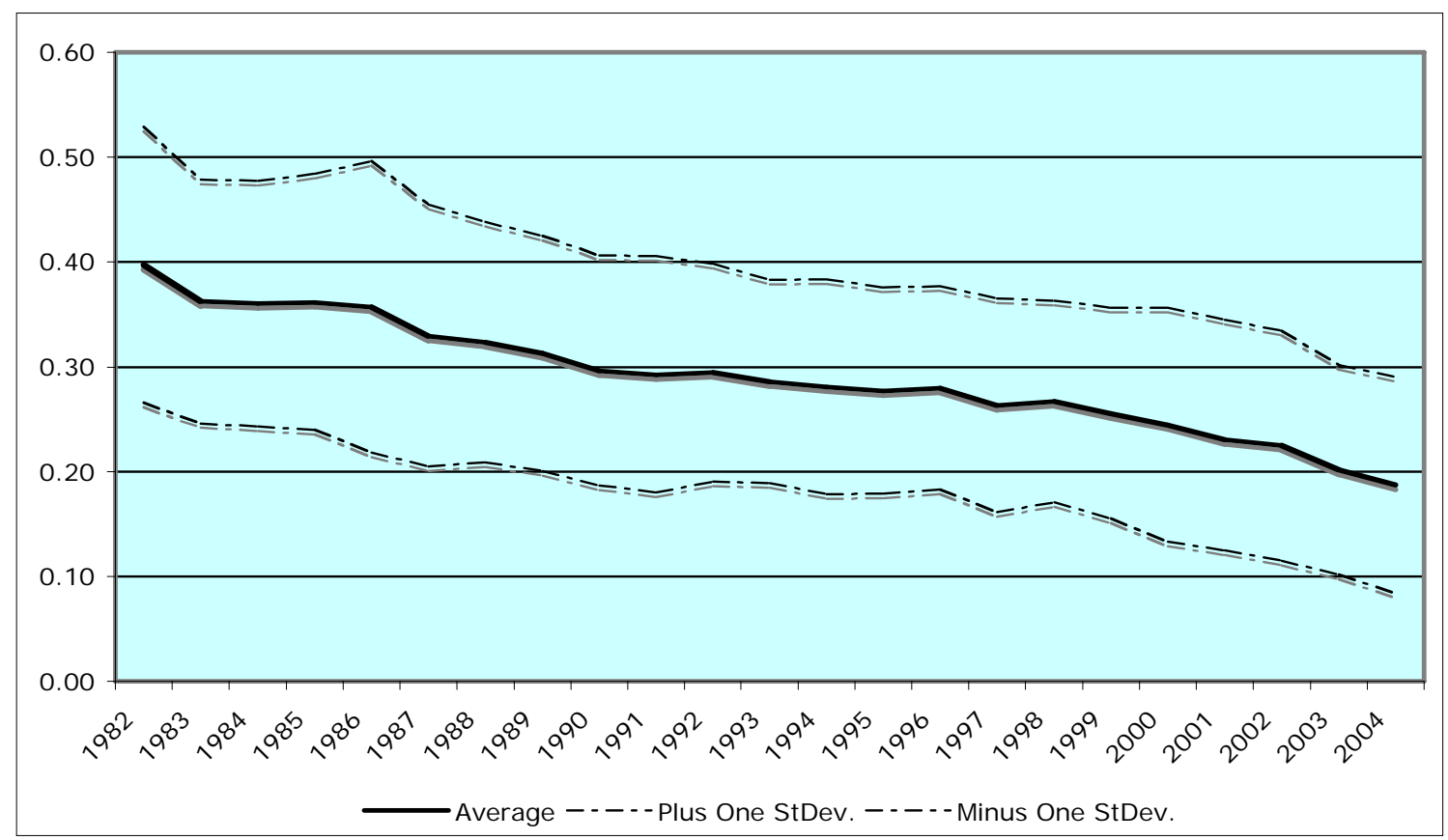

\footnotetext{
${ }^{38}$ Statutory tax rate data are from PricewaterhouseCoopers, Corporate Taxes: Worldwide Summaries. Effective tax rate data are calculated as foreign income taxes paid relative to net (pre-tax) income for U.S. affiliates operating in a particular country. These data are from the Bureau of Economic Analysis (BEA); they are discussed further in Appendix A.
} 
Figure 2: Where Were the Profits in 2003?

(profits as a percentage of the worldwide total)

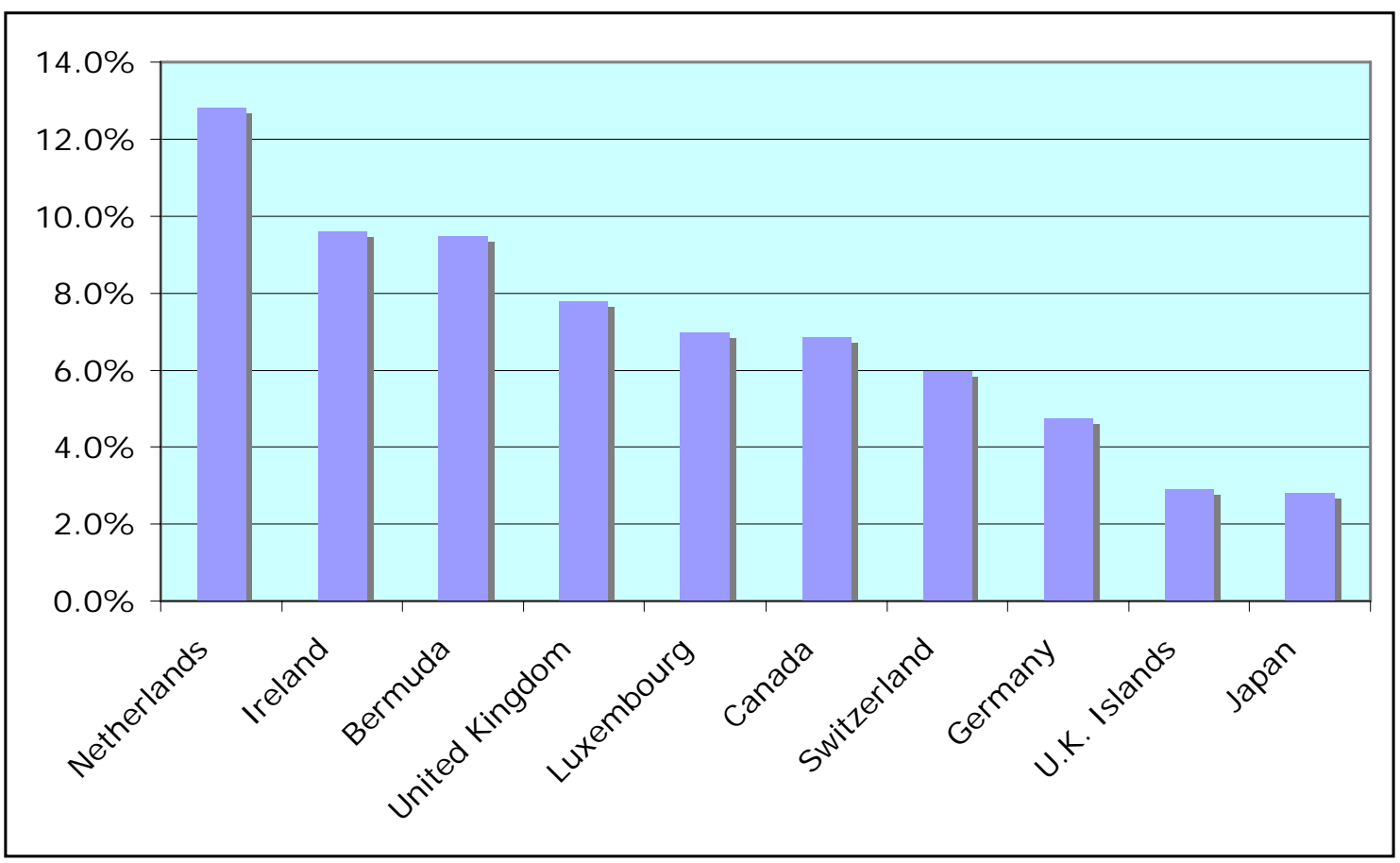

\begin{tabular}{lr}
\hline Country & Effective Tax Rate \\
\hline Netherlands & $5.3 \%$ \\
Ireland & $6.1 \%$ \\
Bermuda & $1.7 \%$ \\
United Kingdom & $20.1 \%$ \\
Luxembourg & $-1.8 \%$ \\
Canada & $23.5 \%$ \\
Switzerland & $4.5 \%$ \\
Germany & $8.2 \%$ \\
U.K. Islands & $1.3 \%$ \\
Japan & $36.9 \%$ \\
\hline
\end{tabular}

Notes: In 2003, majority-owned affiliates of U.S. multinational firms earned \$326 billion of net income. This figure shows percentages of the worldwide (non-U.S.) total net income occurring in each of the top-10 income countries. Thus, each percentage point translates into approximately $\$ 3.3$ billion of net income. Effective tax rates are calculated as foreign income taxes paid relative to net (pre-tax) income. Data are from the Bureau of Economic Analysis (BEA) web page; 2003 is the most recent year with revised data available. The Bureau of Economic Analysis conducts annual surveys of Operations of U.S. Parent Companies and Their Foreign Affiliates. These data are discussed in more detail in Appendix A. 
Figure 3: Where Were the Jobs in 2003?

(employment as a percentage of the worldwide total)

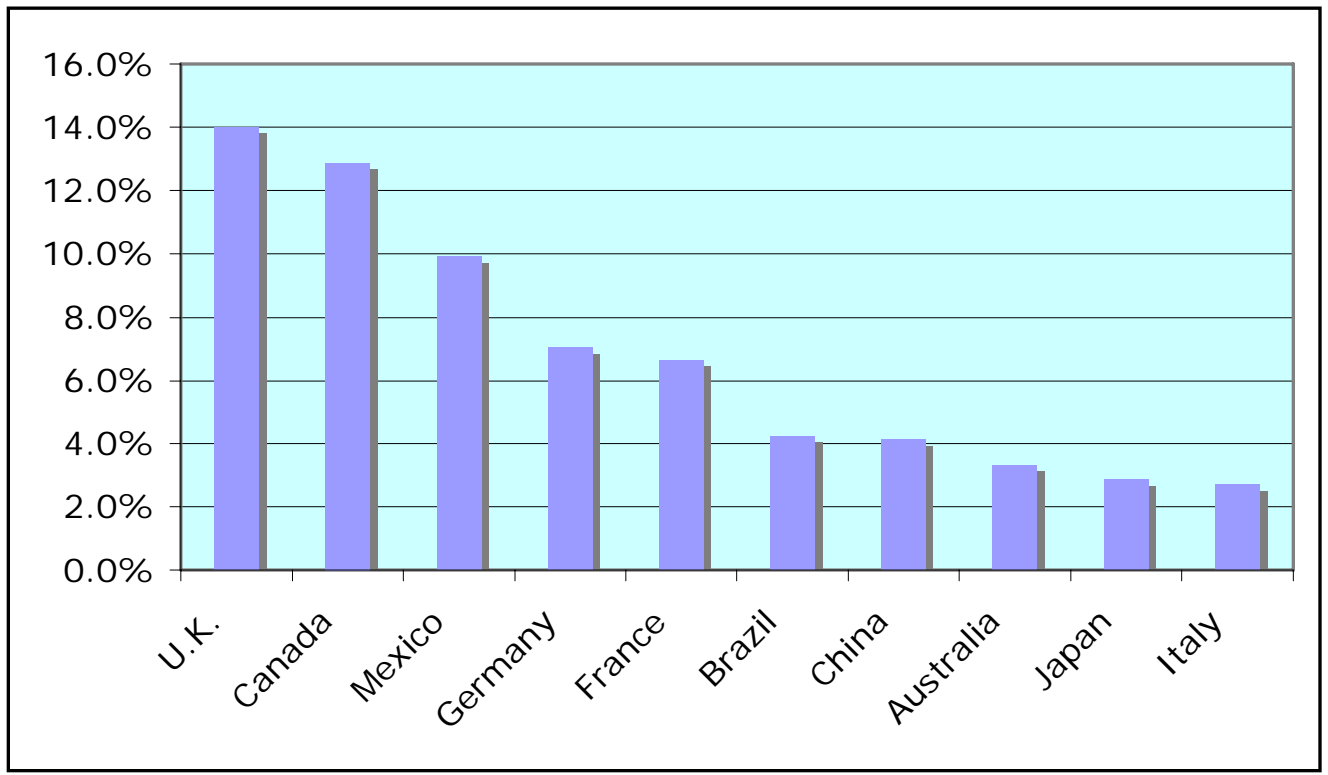

\begin{tabular}{lr}
\hline Country & Effective Tax Rate \\
\hline United Kingdom & $20.1 \%$ \\
Canada & $23.5 \%$ \\
Mexico & $34.8 \%$ \\
Germany & $8.2 \%$ \\
France & $25.1 \%$ \\
Brazil & $65.4 \%$ \\
China & $13.0 \%$ \\
Australia & $28.0 \%$ \\
Japan & $36.9 \%$ \\
Italy & $35.1 \%$ \\
\hline
\end{tabular}

Notes: In 2003, majority-owned affiliates of U.S. multinational firms employed 8.2 million employees. This figure shows percentages of the worldwide (non-U.S.) total employment occurring in each of the top-10 countries. Thus, each percentage point translates into approximately 82,000 jobs. Effective tax rates are calculated as foreign income taxes paid relative to net (pre-tax) income. Data are from the Bureau of Economic Analysis (BEA) web page; 2003 is the most recent year with revised data available. The Bureau of Economic Analysis conducts annual surveys of Operations of U.S. Parent Companies and Their Foreign Affiliates. These data are discussed in more detail in Appendix A. 


\section{Figure 4:}

Central Government Corporate Tax Revenues Relative to GDP, OECD Countries

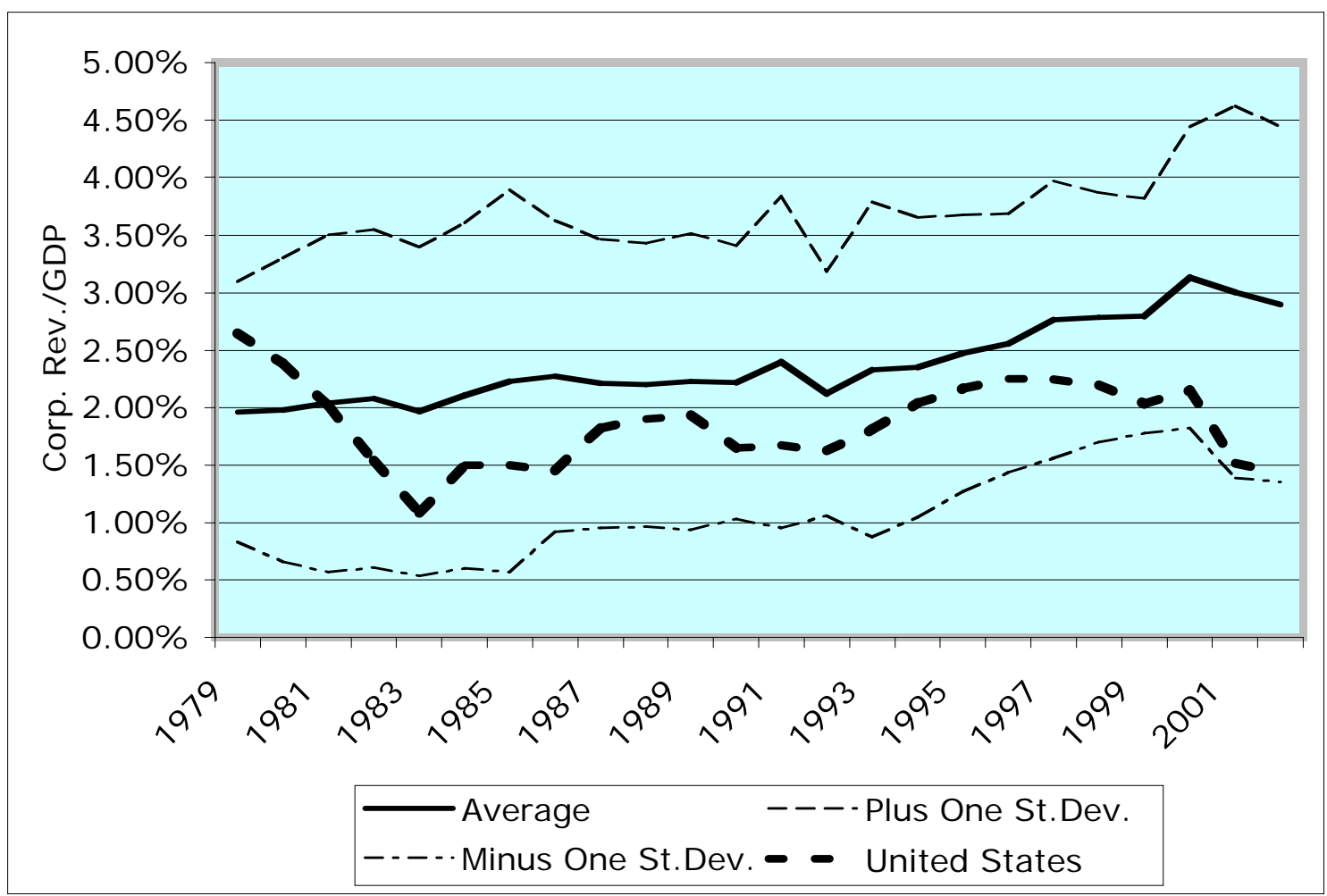

Note: Corporate tax revenue data are from the OECD revenue statistics. GDP data are from the World Bank’s World Development Indicators database. 
Table 1: U.S. Multinational Firm Operations in 2003

(for those countries with the largest U.S. affiliate operations)

\begin{tabular}{|c|c|c|c|c|}
\hline & $\begin{array}{l}\text { (1) } \\
\text { Share of } \\
\text { Sales }\end{array}$ & $\begin{array}{l}\text { (2) } \\
\text { Share of } \\
\text { Income }\end{array}$ & $\begin{array}{l}\text { (3) } \\
\text { Effective } \\
\text { Tax Rate }\end{array}$ & $\begin{array}{l}\text { (4) } \\
\text { Excess Income } \\
\text { Share } \\
\text { (v. Sales) }\end{array}$ \\
\hline Luxembourg & $0.3 \%$ & $7.0 \%$ & $-2 \%$ & $2,585 \%$ \\
\hline Bermuda & $1.4 \%$ & $9.5 \%$ & $2 \%$ & $600 \%$ \\
\hline Barbados & $0.1 \%$ & $0.6 \%$ & $3 \%$ & $324 \%$ \\
\hline U.K. Islands & $0.8 \%$ & $2.9 \%$ & $1 \%$ & $246 \%$ \\
\hline Portugal & $0.3 \%$ & $0.8 \%$ & $6 \%$ & $205 \%$ \\
\hline Netherlands & $4.4 \%$ & $12.8 \%$ & $5 \%$ & $194 \%$ \\
\hline Denmark & $0.4 \%$ & $1.0 \%$ & $11 \%$ & $150 \%$ \\
\hline Ireland & $3.9 \%$ & $9.6 \%$ & $6 \%$ & $146 \%$ \\
\hline Indonesia & $0.4 \%$ & $0.8 \%$ & $40 \%$ & $71 \%$ \\
\hline Switzerland & $4.3 \%$ & $6.0 \%$ & $5 \%$ & $41 \%$ \\
\hline Belgium & $2.1 \%$ & $2.1 \%$ & $11 \%$ & $-3 \%$ \\
\hline Hong Kong & $1.9 \%$ & $1.8 \%$ & $9 \%$ & $-6 \%$ \\
\hline Singapore & $3.4 \%$ & $2.7 \%$ & $7 \%$ & $-19 \%$ \\
\hline Norway & $0.7 \%$ & $0.6 \%$ & $66 \%$ & $-23 \%$ \\
\hline Spain & $2.1 \%$ & $1.6 \%$ & $10 \%$ & $-24 \%$ \\
\hline Taiwan & $0.9 \%$ & $0.7 \%$ & $19 \%$ & $-27 \%$ \\
\hline China & $1.7 \%$ & $1.1 \%$ & $13 \%$ & $-33 \%$ \\
\hline Sweden & $1.7 \%$ & $1.1 \%$ & $20 \%$ & $-33 \%$ \\
\hline Germany & $7.6 \%$ & $4.8 \%$ & $8 \%$ & $-37 \%$ \\
\hline Korea, Republic of & $0.7 \%$ & $0.4 \%$ & $28 \%$ & $-39 \%$ \\
\hline Thailand & $0.7 \%$ & $0.4 \%$ & $39 \%$ & $-43 \%$ \\
\hline United Kingdom & $14.0 \%$ & $7.8 \%$ & $20 \%$ & $-44 \%$ \\
\hline Malaysia & $1.1 \%$ & $0.6 \%$ & $23 \%$ & $-48 \%$ \\
\hline Australia & $2.6 \%$ & $1.3 \%$ & $28 \%$ & $-48 \%$ \\
\hline Japan & $5.9 \%$ & $2.8 \%$ & $37 \%$ & $-52 \%$ \\
\hline Mexico & $3.9 \%$ & $1.6 \%$ & $35 \%$ & $-58 \%$ \\
\hline France & $5.2 \%$ & $2.0 \%$ & $25 \%$ & $-61 \%$ \\
\hline Argentina & $0.6 \%$ & $0.2 \%$ & $45 \%$ & $-64 \%$ \\
\hline Italy & $3.0 \%$ & $1.0 \%$ & $35 \%$ & $-66 \%$ \\
\hline Brazil & $2.2 \%$ & $0.2 \%$ & $65 \%$ & $-92 \%$ \\
\hline
\end{tabular}

Countries are selected for inclusion in this table if either their sales share or their income share exceeds one half of one percent of worldwide totals. Data are from the Bureau of Economic Analysis (BEA) web page; 2003 is the most recent year with revised data available. The Bureau of Economic Analysis conducts annual surveys of Operations of U.S. Parent Companies and Their Foreign Affiliates. These data are discussed in more detail in Appendix A. 


\section{References}

Altshuler, Rosanne. 2000. "Recent Developments in the Debate on Deferral.” Tax Notes. 10 April. 255-68.

Altshuler, Rosanne and Jonathan Ackerman. 2005. “International Aspects of Recommendations from the President's Advisory Panel on Federal Tax Reform.” International Tax Policy Forum Presentation. 2 December.

Altshuler, Rosanne and Harry Grubert. 2006. "Corporate Taxes in the World Economy: Reforming the Taxation of Cross-Border Income.” Working Paper. December.

Agundez-Garcia, Ana. 2006. “The Delineation and Apportionment of An EU Consolidated Tax Base for Multi-Jurisdictional Corporate Income Taxation: A Review of Issues and Options.” European Commission Taxation Paper no. 9. October.

Arnold and McDonnell. (1993). Brian J. Arnold and Thomas E. McDonnell, Report on the Invitational Conference on Transfer Pricing: the Allocation of Income and Expenses Among Countries. Tax Notes. 13 December. 1377- 1381.

Auerbach, Alan. 2006. "Why Have Corporate Tax Revenues Declined? Another Look." NBER Working Paper no. 12463. Cambridge. August.

Avi-Yonah, Reuven. 2005. "The Silver Lining: The International Tax Provisions of the American Jobs Creation Act - A Reconsideration." Bulletin for International Fiscal Documentation 59, no. 1 (2005): 27-35.

Avi-Yonah, Reuven. 2006. “The Rise and Fall of Arm’s Length: A Study in the Evolution of US International Taxation.” Finance and Tax Law Review 9:310 (updated version of article from 1995 Virginia Tax Review, 15:89).

Bucks, Dan R., and Michael Mazerov. 1993. “The State Solution to the Federal Government's International Transfer Pricing Problem.” National Tax Journal. 46(3). 385-92.

Clausing, Kimberly A. 2007a "Corporate Tax Revenues in OECD Countries.” International Tax and Public Finance, 14, April, 115-33.

Clausing, Kimberly A. 2007b. "Multinational Firm Tax Avoidance and U.S. Government Revenue.” Working paper.

Clausing, Kimberly A. 2005. “Tax Holidays (and Other Escapes) in the American Jobs Creation Act.” National Tax Journal 58(3). September. 1-16. 
de Mooij, Ruud A. 2005. “Will Corporate Income Taxation Survive?” De Economist. 153. 277-301.

de Mooij, Ruud A. and Sjef Ederveen. 2003. “Taxation and Foreign Direct Investment: A Synthesis of Empirical Research” International Tax and Public Finance. 10 No. 6 (November): 673-93.

Desai, Mihir. 2003. “The Divergence Between Book Income and Tax Income”. In Poterba, James M., ed. Tax Policy and the Economy. 17. 169-206.

Desai, Mihir. 2005. “The Degradation of Reported Corporate Profits.” Journal of Economic Perspectives. 19(4). Fall. 171-192.

Durst, Michael C. 2007. “New Statutory Language To Govern Transfer Pricing Under Section 482.” Working Paper.

Durst, Michael C. and Robert E. Culbertson. 2003. "Clearing Away the Sand: Retrospective Methods and Prospective Documentation in Transfer Pricing Today.” Tax Law Review. 57. 37-84.

Edmiston, Kelly D. 2002. "Strategic Apportionment of the State Corporate Income Tax." National Tax Journal. 55(2). 239-262.

Eichner, Thomas and Marco Runkel. 2006. "Why the European Union Should Adopt Formula Apportionment with a (Double) Sales Factor.” Working Paper.

Ernst and Young. 2005 and 2006. “2005-2006 Global Transfer Pricing Surveys.” Available on-line at www.ey.com/transferpricingsurvey; accessed Jan 4, 2007.

Fleming Jr., J. Clifton and Robert J. Peroni. “Eviscerating the Foreign Tax Credit Limitations and Cutting The Repatriation Tax - What's ETI Repeal Got to Do With It?” Tax Notes. (September 20, 2004): 1393-1415.

Gnaedinger, Chuck and Lisa M. Nadal. 2007. “Kovacs Optimistic On CCTB Despite Opposition.” Tax Notes International 45. March 5, 2007. 935.

Glenn, Heidi. “House-Passed ETI Bill Sets Stage for Difficult Conference.” Tax Notes (June 21, 2004): 1439.

Goolsbee, Austan and Edward Maydew. 2000. "Coveting Thy Neighbor's Manufacuring: The Dilemma of State Income Apportionment.” Journal of Public Economics. 75. 125-143.

LeGall, Jean Francois. 2006. "When Is a Subsidiary a Permanent Establishment of Its Parent?” Tillinghast Lecture, New York University (forthcoming in Tax Law Review). 
Marshall, Alfred. 1890. Principles of Economics.

Omer, Thomas C., and Marjorie K. Shelley. 2004. "Competitive, Political, and Economic Factors Influencing State Tax Policy Changes." Journal of the American Tax Association. 26 (s1). 103-126.

Report of the President's Advisory Panel on Federal Tax Reform. 2005. Simple, Fair, and Pro-Growth: Proposals to Fix America's Tax System. November. Washington: Government Printing Office.

Shackleford, Douglas and Joel Slemrod. 1998. “The Revenue Consequences of Using Formula Apportionment to Calculate U.S. and Foreign-Source Income: A FirmLevel Analysis.” International Tax and Public Finance. 5(1). 41-59.

Sorensen, Peter Birch. 2004. “Company Tax Reform in the European Union.” International Tax and Public Finance. 11(1). 91-115.

Taylor, Willard. Testimony before the President's Advisory Panel on Federal Tax Reform. March 31, 2005. In Tax Notes (April 4, 2005) Doc 2005-6654.

U.S. Treasury (2006). Technical Explanation of United States Model Income Tax Convention. Washington: Government Printing Office.

Weiner, Joann Martens. 2005. "Formulary Apportionment and Group Taxation in the European Union: Insights from the United States and Canada.” European Commission Taxation Working Paper no. 8. March. 


\section{Appendix A: Estimates of Revenue Gain Due to Formula Apportionment}

This appendix considers methods of estimating the revenue gain to the United States government due to formula apportionment. All of these methods rely on multiple assumptions and simplifications. The data are imperfect and incomplete. Further, there are multiple margins under which this change would affect multinational firm behavior both in the United States and abroad, and there is substantial uncertainty regarding the net influence of these responses on government revenues. Finally, the actual legislation and accompanying regulations implementing FA would matter a great deal in terms of ultimate effects on revenue.

Therefore, all of these estimates should be treated with a great deal of caution, as a mere starting point for thinking about this question. That said, estimates below paint a broadly consistent picture of large U.S. government revenue gains with the adoption of formula apportionment.

1. The simplest estimate of the revenue gain relies on inferences from the U.S. Bureau of Economic Analysis (BEA) data regarding the operations of U.S. multinational firms. According to 2003 data from the BEA, U.S. multinational firms earn $56.7 \%$ of their worldwide net income in the United States. However, $69.6 \%$ of worldwide sales for these firms occurs in the United States. If the United States tax base were $69.6 \%$ of worldwide income, it would increase by $\$ 149$ billion. With the increment taxed at the marginal tax rate of $35 \%$, that would generate $\$ 52$ billion in additional revenue. Since revenues from the corporate income tax in 2003 were $\$ 131.8$ b, that represents an increase of $40 \%$. The following Table shows the results of the same calculations for the three most recent years with available data. 2002, however, was likely an usual year, as net income in the United States was abnormally low in comparison with other years.

\begin{tabular}{|c|c|c|c|}
\hline & 2002 & 2003 & 2004 \\
\hline Fraction of World Sales in United States & $71.6 \%$ & $69.6 \%$ & $68.2 \%$ \\
\hline Fraction of World Income in United States & $8.2 \%$ & $56.7 \%$ & $56.0 \%$ \\
\hline Implied New Tax Revenue & $\$ 79$ billion & $\$ 52$ billion & $\$ 53$ billion \\
\hline $\begin{array}{l}\text { Implied New Tax Revenue as Share of } \\
\text { Same Year's Federal Corporate Tax } \\
\text { Receipts }\end{array}$ & $54 \%$ & $40 \%$ & $28 \%$ \\
\hline
\end{tabular}

If one assumes instead that the increment were taxed at the average tax rate that was paid on corporate profits, then this increase would be smaller. Yet in other ways, this estimate represents an underestimate of the revenue gain since it includes only U.S. multinational firms. Foreign-owned multinational firms with 
affiliates in the United States would also face changes in their tax treatment that will increase revenues as long as the fraction of their worldwide sales in the United States exceeds the fraction of their worldwide income booked in the United States. While this is not possible to ascertain given the absence of BEA data on foreign parent firms, profits do appear to be disproportionately low for these firms relative to their sales in the United States. For example, in 2003, net income of U.S. parent multinational firms is $6.5 \%$ of their U.S. sales, while net income for U.S. affiliates of foreign parent firms is $1.4 \%$ of their U.S. sales.

A final issue concerning these calculations is the possibility of double-counting in the BEA net income figures. These figures include "income from equity investments”, some of which may be counted more than once if there are tiers of holdings within the same country. Unfortunately, from existing BEA data, it is impossible to tell exactly how large this problem is, or how much this problem is correlated with the tax rate of the country in question. ${ }^{39}$ Using an alternative data series from the BEA on direct investment earnings, one can exclude all income from equity investments, but this too is conceptually inappropriate. Still, I performed calculations that employed this series nonetheless. To make the data comparable to net income, I adjusted for the fact that direct investment earnings were pro-rated to reflect the ownership stake of the U.S. parent, assuming an average ownership stake of $68.6 \%$ for all firms. (This was the average ownership stake in 2003.) One finds a very similar fraction of worldwide income abroad, roughly 57\% in both 2003 and 2004. Estimates of revenue gain from FA are about a third smaller, due to some combination of a narrower definition of income as well as the elimination of any double-counting.

2. Clausing (2007b) undertakes estimates of the revenue lost to the United States due to income shifting by U.S. multinational firms. These are based on regressions that consider how profit rates (profit to sales ratios) depend on affiliate country tax rates. For the decade 1995 to 2004, the regression results indicate that a tax rate one percentage point higher (relative to the United States) is associated with an affiliate profit rate .5 to .8 percentage points lower. This result is used, together with information regarding profits and sales for each country and year, to calculate how profits would be different absent tax influences, and thus how revenue would be different in the United States absent income shifting.

Results vary by year, by whether one employs a statutory or an effective tax rate in the regression analysis, and by the assumption regarding the U.S. tax rate that would apply to higher levels of income in the United States. One representative calculation finds that in 2002, U.S. corporate profits would be $\$ 170$ billion higher absent income shifting. This additional profit generates $\$ 54$ billion in tax revenue, assuming additional profits are taxed at an effective tax rate of $32 \%$.

${ }^{39}$ Using German data, Weichenrieder (2006) finds no relationship between the tax rates of host countries and more complicated ownership chains. However, other tax factors are important, including whether the investing country has a credit or exemption tax system. 
Since corporate tax revenues in 2002 were \$148 billion, this represents a 37\% increase in tax revenue.

Some estimates are lower or higher than this number. For the years 2001 to 2004, the average estimate indicates an increase in revenue of 38\%, assuming new U.S. profits are taxed at an effective rate of 32\%. Estimates are lower employing a statutory tax rate in the regressions (compared to an effective tax rate), and estimates are lower in 2001 or 2002 (compared to 2003 or 2004).

While these calculations are intuitively plausible, several assumptions are embedded that could cause the results to be underestimates or overestimates. For example, it is assumed that all profit shifting occurs between the United States and affiliate countries, rather than among affiliate countries. This consideration would make this estimate of revenue gain too high. Still, estimates consider only the activities of U.S. multinational firms; this consideration would make this estimate too low, as foreign-based multinational firms likely engage in income shifting away from their United States affiliates.

3. Other studies have generated estimates of a similar magnitude. The most thorough estimate is Shackleford and Slemrod (1998); they use accounting data in financial reports for 46 large U.S. based multinational corporations over the period 1989 to 1993 to estimate changes in revenue under a FA system.

Their estimates are based on firm financial statements and the related income tax footnotes. Three certified public accountants interpreted each detailed disclosure. Both domestic and foreign taxable income were estimated as the sum of the current relevant tax provisions and credits divided by the relevant statutory tax rate; worldwide income is then the sum of domestic and foreign income. The U.S. tax liability under formula apportionment is then calculated as the product of worldwide taxable income, the formula for the fraction of income allocated to the United States, and the U.S. tax rate.

The authors find that FA raises tax liabilities for some industries and firms, lowering burdens for others. They estimate that the oil and gas industry would see an increase in tax liabilities of $81 \%$ under FA, compared with $29 \%$ for all other firms in their study. They also estimate that some firms will experience a tax decrease, including Boeing, Procter and Gamble, and Dow Chemical.

Overall, Shackleford and Slemrod (1998) find that revenues would increase by $38 \%$ under a three-factor FA system. This increase is not dependent on any particular factor, and they calculate that a single factor sales formula would increase revenues by $26 \%$. Given the changes in the international tax environment since the time period of their data, and in particular the increasing discrepancy between U.S. corporate tax rates and those of other major countries, these estimates likely understate the current U.S. revenue gain with FA adoption. 
Any of the first three estimates can also be used to generate an estimate of what corporate tax rate would be associated with a revenue neutral implementation of formula apportionment. Taking as one baseline that tax revenues would increase by $35 \%$ with formula apportionment, this implies that the corporate tax rate could be lowered by 9 percentage points, to $26 \%$. Of course, one could also pursue an intermediate policy that lowered the corporate tax rate less but that also modestly increased tax revenue.

Note that the estimates discussed above are based on book income figures, not tax income. Numbers (1) and (2) utilize data from the BEA surveys on multinational firms; number (3) uses data from firm financial statements. It would be preferable to utilize data on tax income, which is also presumably more responsive to tax incentives; however, this is not possible absent access to Treasury data. Also note that none of these estimates address methods that firms utilize to lower their taxable income overall; the focus is instead on the sourcing of income. 


\section{Appendix B: Other Formula Choices}

Section III of the paper explains the merits of employing a sales-based formula rather than the traditional "Massachusetts formula" which is an equal-weighted average of sales, payroll, and asset shares. A sales based formula has several advantages. First, firms have little ability to undertake tax avoidance strategies with a destination-based sales formula, since firms have no control over where customers are located. ${ }^{40}$ Second, this avoids an implicit tax on payroll and assets, which can distort multinational firms' investment and employment decisions. Third, U.S. states have demonstrated a tendency to increase the sales weight over time, so adopting a sales based formula at the outset may encourage countries to adopt more uniform formulas.

Still, multiple factor formulas have some advantages. First, while the incidence of the corporate tax is a complex matter, beyond the scope of this paper, one advantage of the equal-weighted formula is that the incidence of the tax may be more ideal. For example, some argue that the asset portion of the formula is particularly compatible with the desire to have the corporate tax be born by capital. Second, some argue that a three-factor formula more adequately captures the supply side of the process that generates profit. Still, as was recognized as far back as Marshall (1890), value has its roots in both supply and demand factors, and trying to separate them is as futile as trying to determine which blade of the scissors cuts. Third, to the extent that firms are able to manipulate the destination of their sales (which we deem unlikely; see text), a multiple factor formula would make that type of avoidance more difficult. Finally, to the extent that some countries view a sales-based formula as not suited to their interests, a formula with several factors could be viewed as a useful compromise.

In addition to a sales-based formula and an equally-weighted formula, some have suggested a formula with a double weight on sales. For example, Eichner and Runkel (2006) argue that such a formula would reduce the harmful effects of tax competition, as the fiscal externalities of corporate income taxation would be minimized.

Sorensen (2004) and Agundez-Garcia (2006) have discussed the possibility of using industry or macro-based weights in these formulas. Thus, a firm's tax liability in a particular country would not depend on their own share of worldwide activity in the country, but rather on the industry-wide average of these shares. If a firm is small relative to the industry, then its own decisions have little effect on where its tax liability is assigned, and firms have no incentive to distort their behavior. However, this method has the downside of separating a firm's activities from the jurisdictions in which it incurs taxation, which would likely prove too arbitrary. In the extreme, if macro-weights were used, a firm's tax liability in a given country would depend on, e.g., the size of that country in the world economy. So if the United States were one quarter of the world economy, any firm with nexus in the United States would have a U.S. tax base equal to one quarter of their worldwide profits, even if the particular firm did 1\% (or 99\%) of their activity in the United States. This would strike many as unduly arbitrary.

${ }^{40}$ Of course this assumes that the definition of a unitary business is sufficient to prevent manipulation of the destination of sales. This issue is discussed in the paper. 